DOI

\title{
УЛЬТРАСТРУКТУРНІ ОСОБЛИВОСТІ РЕОРГАНІЗАЦІї ЕЛЕМЕНТІВ СТІНКИ СЕЧОВОГО МІХУРА ЖІНОК РАННЬОГО ТА ПІЗНЬОГО МЕНОПАУЗАЛЬНИХ ПЕРІОДІВ
}

\author{
ФБ. Ю. Бідованець, Т. К. Головата
}

ДВНЗ «Тернопільський державний медичний університет імені І. Я. Горбачевського МОз України»

РЕЗЮМЕ. У роботі представлені результати дослідження проявів ремоделювання структурних компонентів сечового міхура жінок у менопаузальному періоді на ультраструктурному рівні. Доведено однотипність виникнення та проґресування ультраструктурних змін залежно від віку та ступеня розладів мікрогемодинаміки. Встановлено, що у паренхіматозних та стромальних клітинах виникають неспецифічні проґредієнтні дистрофічні зміни. Виявлено морфологічні еквіваленти зниження функціональної активності ендотеліоцитів гемокапілярів, що свідчить про порушення транскапілярного обміну, поглиблення гіпоксії та посилення колагеносинтезуючої функції фібробластів.

КЛЮчОВІ СЛОВА: сечовий міхур, менопауза.

Вступ. Частота дисфункцій сечового міхура серед жіночого населення найчастіше спостерігається у віці після 45 років - у $61 \%$ у у $40-45$ років - у $23 \%$, і до 40 років - у $16 \%$, причому лише 29 \% жінок своєчасно звертаються до лікарів [1]. Найчастішим проявом старіння сечового міхура $\epsilon$ невтримування сечі, що зустрічається, за даними різних дослідників, в 4-40\% жінок [2-6]. Нетримання сечі супроводжується розвитком інфекцій сечовивідних шляхів, призводить до зниження працездатності, соціальної та психічної дезадаптації.

Вважають, що це проблема жінок переважно менопаузального періоду і можливості її вирішення пов'язані з корекцією вікової недостатності функції яєчників $[7,8]$. Водночас причини і способи корекції порушень сечовипускання у жінок перименопаузального періоду вивчені недостатньо. Патоґенез дизурій складний, багатофакторний, $\epsilon$ предметом дискусій і на сьогоднішній день до кінця не вивчений.

Мета дослідження - встановити морфологічні прояви перебудови структурних компонентів стінки сечового міхура у жінок раннього та пізнього менопаузальних періодів на ультраструктурному рівні.

Матеріал і методи дослідження. Досліджено 48 біоптатів слизової оболонки сечового міхура жінок раннього (20 осіб) та пізнього менопаузального періодів (28 осіб) з дизуричними розладами в анамнезі та за даними функціонального обстеження. Забір матеріалу для електронномікроскопічного вивчення структурних компонентів стінки сечового міхура здійснювали під час цистоскопії за загальноприйнятими правилами. Матеріал фіксували у 2,5 \% розчині глютаральдегіду з активною реакцією середовища $\mathrm{pH} 7,3-7,4$, приготовленому на фосфатному буфері Міллоніга. Фіксований матеріал через 50-60 хвилин пере- носили у буферний розчин і промивали протягом 20-30 хвилин. Постфіксацію здійснювали 1 \% розчином чотириокису осмію на буфері Міллоніга протягом 60 хвилин, після чого проводили його дегідратацію в спиртах і ацетоні та заливали в суміш епоксидних смол і аралдиту. Ультратонкі зрізи, виготовлені на ультрамікротомах УМПТ-7, забарвлювали 1 \% водним розчином уранілацетату, контрастували цитратом свинцю згідно 3 методом Рейнольдса та вивчали в електронному мікроскопі ПЕМ-125К.

Результати й обговорення. При ультраструктурному аналізі стінки сечового міхура жінок раннього менопаузального періоду чіткі структурні зрушення виявляли з боку мікроциркуляторного русла. Просвіт більшості гемокапілярів слизової оболонки був розширеним і обмеженим ендотеліальними клітинами двох типів - «темними» і «світлими». Плазмолема «темних» ендотеліоцитів на значному протязі формувала вирости, цитоплазма яких була повністю заповненою дрібними піноцитозними міхурцями. Кількість везикул збільшувалася по всій цитоплазмі, особливо вздовж люмінальної поверхні клітин. У деяких випадках можна було спостерігати крайове стояння піноцитозних міхурців, які знаходилися у стадії завантаження. В “світлих» ендотеліоцитах люмінальна поверхня була рівною. Цитоплазма цих клітин виглядала світлою з осередками спустошення.

В гемокапілярах слизової сечового міхура жінок у пізньому періоді менопаузи електронномікроскопічно спостерігалися дистрофічні та атрофічні зміни. Цитоплазма ендотеліальних клітин в основному була електронно прозора. Периферійні ділянки їх були стоншені, містили велику кількість мікропіноцитозних везикул, які часто зливалися і утворювали більш крупні. Тут же зустрічалися поодинокі мітохондрії та елементи 
Огляди літератури, оригінальні дослідження, погляд на проблему

гранулярної цитоплазматичної сітки. Ядровмісна ділянка ендотеліоцитів мала вигляд значно потовщеної і виступала в просвіт капілярів (рис. 1).

Ядра ендотеліоцитів були овальної форми, контури - в основному рівні. Каріоплазма містила дрібнозернистий дисперсний хроматин та екс- центрично розміщений гетерохроматин. В каріоплазмі осміофільні гетерохроматинові ділянки локалізовані біля каріолеми, а центральна частина її $\epsilon$ електронно-світлою. Ядерні мембрани місцями нечіткі, перинуклеарний простір локально розширений, а ядерні пори виявляються погано.

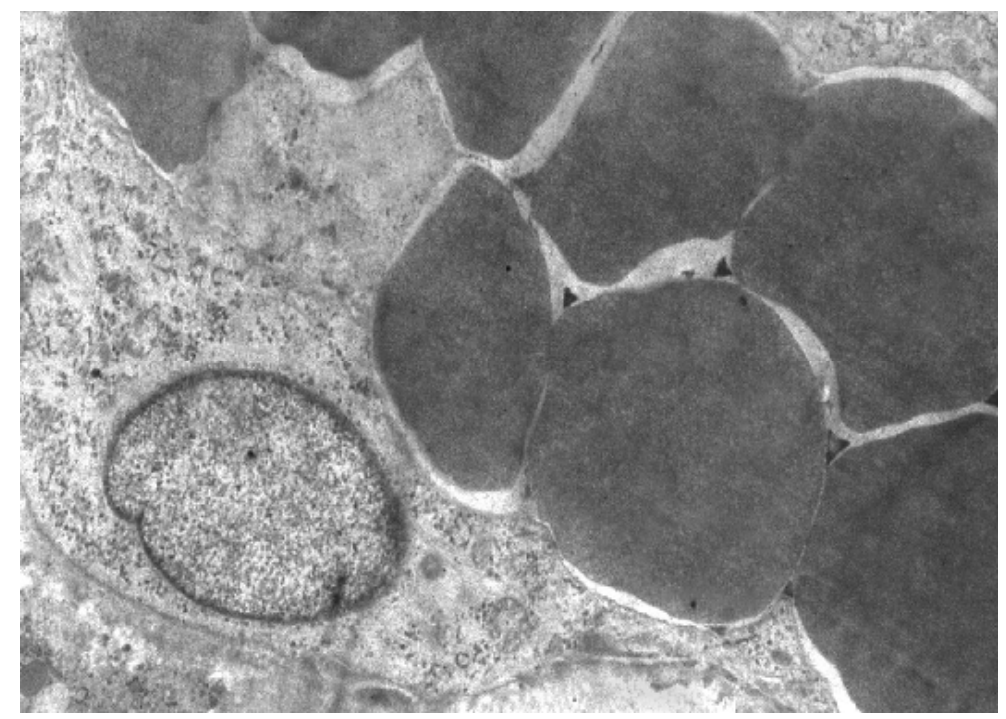

Рис. 1.Електронограма гемокапіляра слизової оболонки сечового міхура пацієнтки пізнього менопаузального періоду. Стаз крові в просвіті капіляра. Ендотеліоцит стоншений із неоднорідною цитоплазмою. Ядро в основному зберігає рівні контури. × 14000.

Плазматична мембрана ендотеліоцитів, обернена в просвіт капілярів, утворювала виступи, найчисельніші на крайових ділянках клітин.

Базальні мембрани капілярів зберігали свою неперервність, але часто були потовщені, місцями розрихлені, місцями - відшаровувалися від ендотеліоцитів і перицитів.

Цитоплазма ендотеліоцитів кровоносних капілярів міокарда має різну електронну щільність. Поряд із темними зустрічалися світлі ендотеліоцити. Латеральні відділи цитоплазми неоднакової товщини, часто стоншені і містять піноцитозні міхурці частіше у вигляді крупних вакуолей. У деяких клітинах латеральні ділянки повністю електронно прозорі. Базальна мембрана капілярів нерівномірно потовщена, розрихлена. У набряклій цитоплазмі мало органел, вони частково пошкоджені. Характерним $\epsilon$ невисокий вміст піноцитозних пухирців і кавеол. Люмінальна поверхня ендотеліоцитів має поодинокі мікроворсинки, наявні окремі цитоплазматичні випинання. Базальна мембрана гемокапілярів нерівномірна, має потовщені світлі ділянки. У таких місцях вона погано контурується.

Подібні прояви призводили до прогресуючого погіршення мікроциркуляції i, як наслідок, поглиблення гіпоксичних впливів, дистрофічнодеструктивних змін та активації фібробластів.
У власній пластинці електронномікроскопічно виявлялися клітини фібробластного ряду, починаючи від малодиференційованих юних фібробластів до зрілих активних форм.

У цитоплазмі молодих клітин були виявлені вільні рибосоми і полісоми, слабо виражений пластинчастий комплекс, малочисленні вузькі або злегка розширені короткі канали гладенької ендоплазматичної сітки та поодинокі включення ліпідів.

Більш зрілі клітини мали веретеноподібну форму та відрізнялися великим вмістом розширених канальців ендоплазматичної сітки, заповнених дрібнодисперсним вмістом дещо зменшеної електронної щільності. Визначалися також округлі або подовжені мітохондрії із незначно ущільненим матриксом.

У групі жінок пізнього менопаузального періоду в підслизовому шарі зустрічалися значні осередки скупчення фібробластів. Останнім були притаманні ознаки метаболічних процесів активності. Цитоплазматичний матрикс фібробластів вміщав значну кількість мікровезикул та канальців. Крім органел у ньому хаотично розміщувалися фібрилярні компоненти.

Більшість вакуольних структур цитоплазми фібробластів локалізувалися поблизу цитоплазматичної мембрани. У матриксі цитоплазми чітко виявлялися скупчення полісом і комплекс Голь- 
Огляди літератури, оригінальні дослідження, погляд на проблему

джі з розвинутими каналами, від яких відшаровувалися багаточисленні вакуолі.

Нерідко на поверхні каріоплазми утворювалися глибокі вирости та інвагінації, що супрово- джувалося конденсацією гетерохроматину поблизу ядерної мембрани. 3'являлися мітохондрії з просвітленим матриксом та зруйнованими кристами (рис. 2).

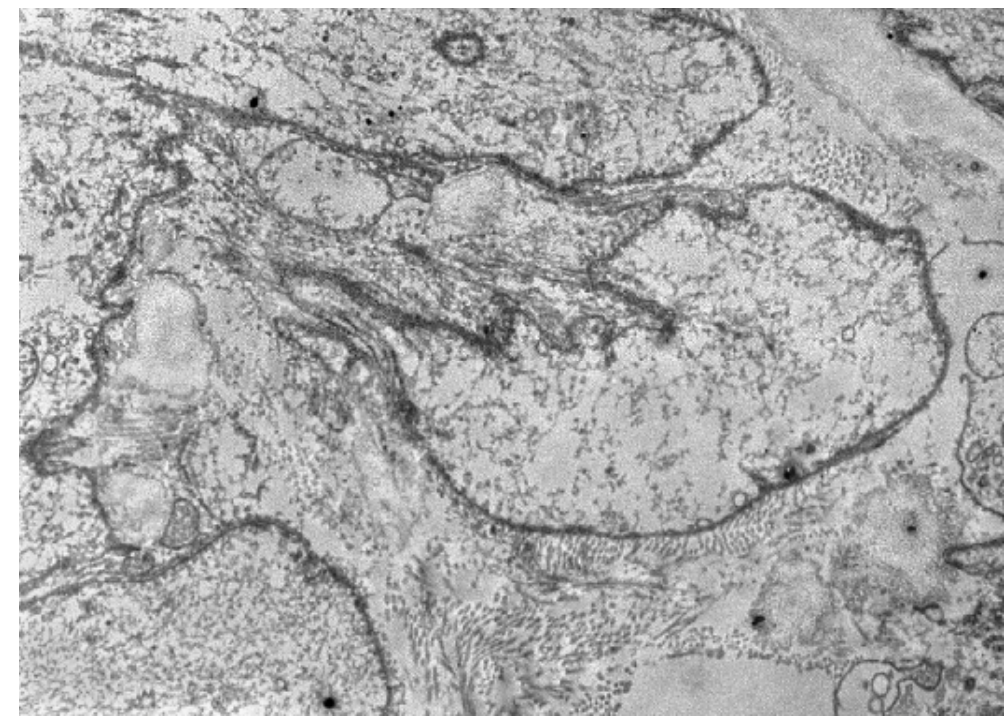

Рис. 2. Електронограма зрілого фібробласта підслизового шару сечового міхура жінки пізнього менопаузального періоду. × 5000.

Електронномікроскопічне дослідження гладком'язових волокон показало, що загалом вони зберігали нормальну структуру. Серед звичайних мітохондрій, рибосом, елементів ендоплазматичної сітки знаходяться філаменти різної товщини без чітко визначеної орієнтації.

У цитоплазмі визначалася дещо зменшена кількість гранул глікогену, у субсарколемальних відділах відмічалось просвітлення матриксу з подушечкоподібними вибуханнями. Ядра містили еухроматин; гетерохроматин знаходився у вигляді вузької смуги, що розміщувалася вздовж внутрішньої мембрани. Ядерця були розміщені ексцентрично. Ядерна оболонка утворювала неглибокі інвагінації (рис. 3). У навколоядерній зоні визначалися комплекс Гольджі, слабо розвинений ендоплазматичний ретикулум, полірибосоми. Міжклітинний простір знаходився в стані незначного набряку, внаслідок чого гемокапіляри і міоцити були ніби розмежовані набряковою рідиною.

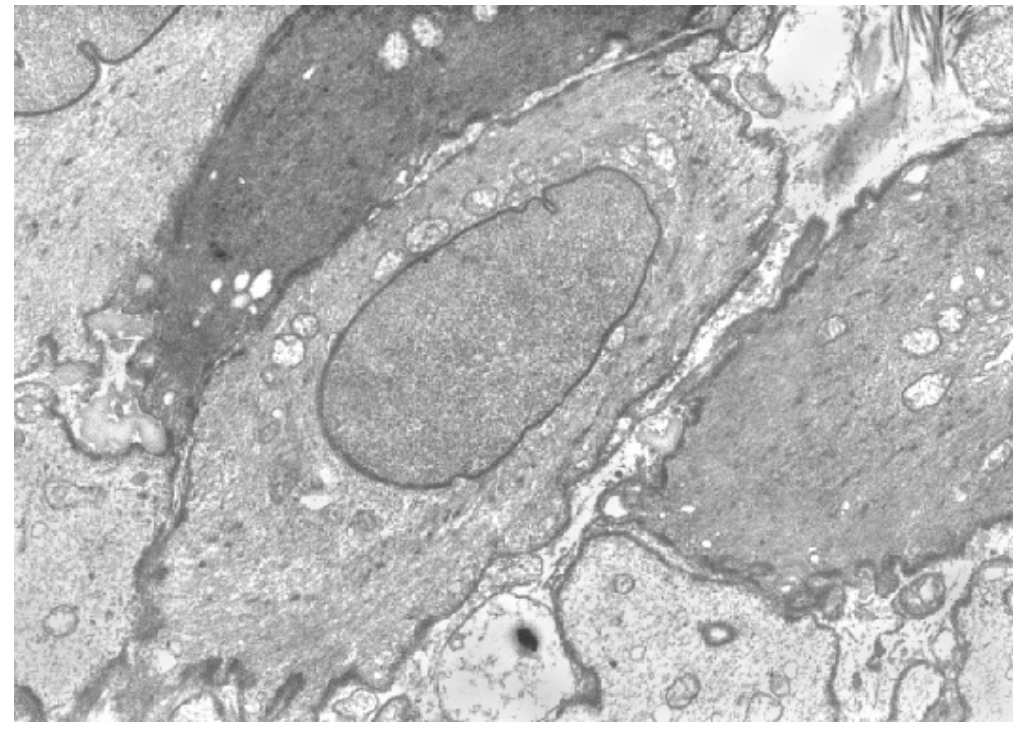

Рис. 3. Електронограма гладкого міоцита сечового міхура жінки раннього менопаузального періоду. Ядро 3 поодинокими неглибокими інвагінаціями. × 5000. 
Огляди літератури, оригінальні дослідження, погляд на проблему

Субмікроскопічне дослідження гладком'язових волокон сечового міхура жінок пізнього менопаузального періоду виявило розвиток деструктивних змін. Міоцити стоншені, подовгасті. На косих та поперечних перерізах видно, що сарколема має нерівні контури. Характерним $є$ зменшення розмірів ядер. Вони зберігають округлу форму, проте їх каріолема має інвагінації та випинання різних розмірів. Перинуклеарний простір вогнищево збільшений, у ядерній оболонці мало ядерних пор. У каріоплазмі наявні невеликі ядерця. Осміофільні гетерохроматинові ділянки ло-

калізовані переважно біля внутрішнього листка ядерної оболонки. Фібрили знаходяться в стані різної функціональної активності, проте більшість перебуває у розслабленому стані. Збільшується кількість осередків лізису фібрил. Розташування останніх зазвичай хаотичне. Упорядковане розташування мітохондрій зберігається, але частина їх гіпертрофована, мають локально просвітлений матрикс та пошкоджені кристи. В цитоплазмі виявляються вакуолеподібні структури, утворені за рахунок канальців саркоплазматичної сітки (рис. 4).

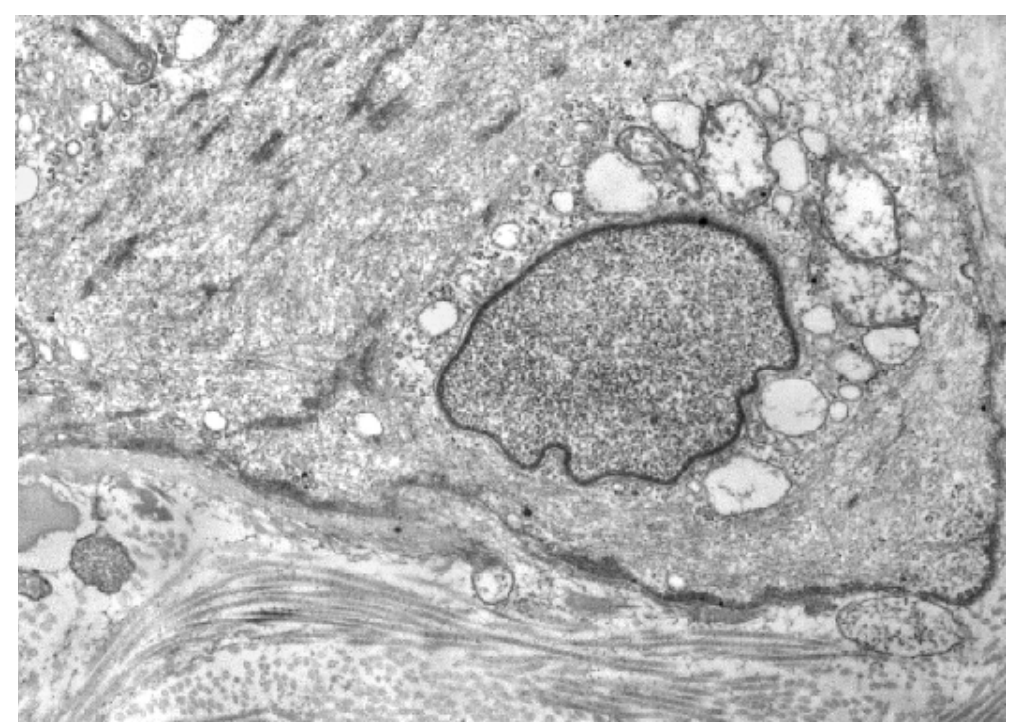

Рис. 4. Електронограма гладкого міоцита сечового міхура жінки пізнього менопаузального періоду. Інваґінації каріолеми, деструктивні явища в мітохондріях, вакуолізація цитоплазми. × 5000.

Міжклітинна речовина сполучнотканинних прошарків значно набрякла. Їх складав електронносвітлий аморфний компонент: окремі пучки колагенових волокон, фрагменти еластичних волокон.

Електронномікроскопічно виявлялася гетерогенність пошкодження клітин перехідного епітелію слизової оболонки досліджуваних сечових міхурів.

У цитоплазмі епітеліоцитів слизової оболонки жінок раннього періоду виявилися краще збережені органели. У частині гіпертрофованих мітохондрій добре структуровані кристи в помірно осміофільному матриксі. У цитоплазмі багато рибосом та полісом, чітко контуруються мембрани гранулярної ендоплазматичної сітки і комплексу Гольджі. В базальній частині клітин спостерігаються округлі та овальні ядра з переважанням в каріоплазмі еухроматину, з ядерцями, також багато рибосомальних гранул. Мембрани ядерної оболонки чіткі, перинуклеарні простори на окремих ділянках помірно розширені, наявні численні ядерні пори. Такий стан компонентів ядра свідчить про підвищення їх функціонування.

Серед малозмінених зустрічалися клітини 3 явищами дистрофії. Дистрофічні зміни в мітохондріях проявлялися вогнищевим просвітленням матриксу і деформацією крист.

Цитоплазма клітин насичена органелами, добре контуровані і помірно розширені канальці гранулярної ендоплазматичної сітки, цистерни і вакуолі в складі комплексу Гольджі розширені не так значно.

Характерними $\epsilon$ активна проліферація і диференціація епітеліальних клітин в базальних шарах. Для таких клітин притаманне високе ядерноцитоплазматичне співвідношення.

У слизовій оболонці жінок пізнього менопаузального періоду малозмінені епітеліоцити зустрічалися значно рідше. Поглиблювалися дистрофічні зміни. Мітохондрії були поліморфними, різними за величиною та формою. В частині з них визначалися помірне набухання і збільшення розмірів, гомогенізація матриксу, 
Огляди літератури, оригінальні дослідження, погляд на проблему вкорочення і розмежування крист, подекуди - їх спустошення.

Особливо виразних змін зазнавали ядра, які

мі характерними були глибокі інвагінації. Гетерохроматин концентрувався маргінально у вигляді грудочок різного кольору. Перинуклеарно втрачали правильну округлу форму. В каріолез'являлася збільшена кількість вакуолей (рис. 5).

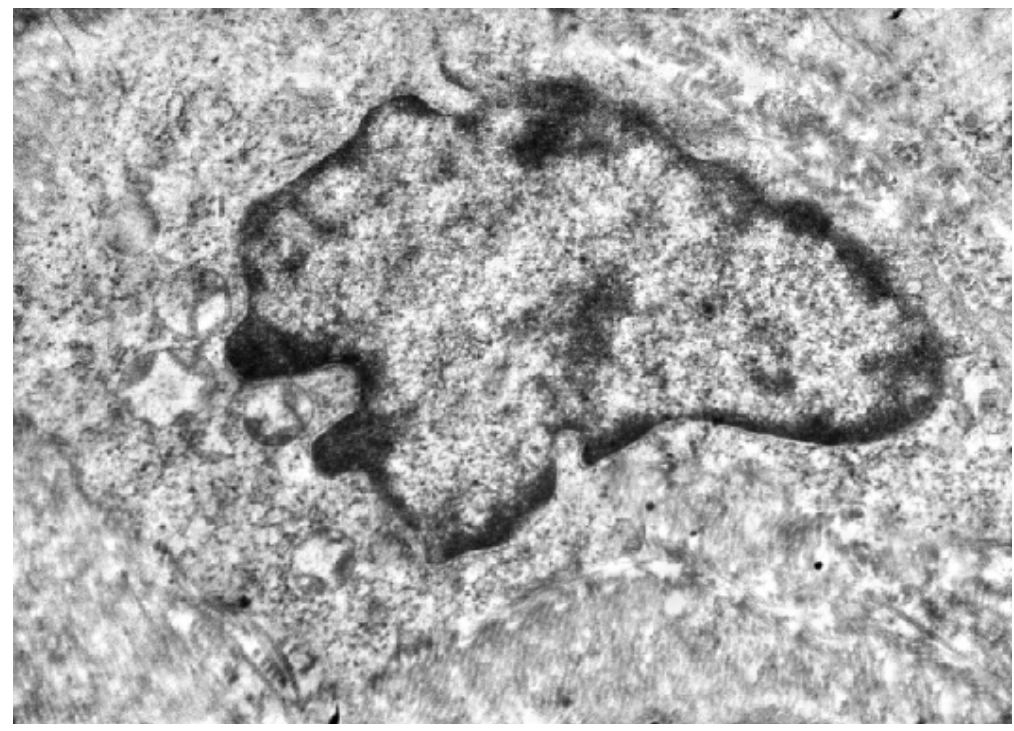

Рис. 5. Електронограма епітеліоцита слизової оболонки пацієнтки пізнього менопаузального періоду. Глибокі інвагінації каріолеми. Нерівномірна концентрація гетерохроматину під оболонкою. Просвітлення матриксу мітохондрій та деструкція крист. × 5000 .

Висновки. У всіх ультраструктурних компонентах слизової оболонки сечового міхура жінок менопаузального періоду відбуваються прогресуючі дистрофічні зміни поряд з явищами компенсації у вигляді гіперплазії енергетичного апарату - мітохондрій, ендоплазматичної сітки і синтетичних процесів. Спостерігається зниження функціональної активності ядер ендотеліоцитів гемокапілярів, що свідчить про порушення транскапілярного обміну, поглиблення гіпоксії та посилення колагеносинтезуючої функції фібробластів.

Перспективи подальших досліджень. Подальші морфологічні дослідження особливостей ремоделювання сечового міхурау жінок менопаузального періоду дозволять обгрунтувати ефективні методи профілактики і лікування дизуричних розладів.

\section{ЛІТЕРАТУРА}

1. Результаты эпидемиологическго исследования распространения нарушений мочеиспускания у женщин [Текст] / И. А. Аполихина, Ф.Н.Мамеджанова, В. Е. Балан, И. А. Курючкина // Гинекология. - 2012. T. 14, № 2. - С. 4-6.

2. Урология по Дональду Смиту [Текст] = Smith's General Urology / под ред. Э. Танахо, Дж. Маканича ; пер. с англ. под ред. В. М. Нечушкиной. - 15-е изд. - М. : Практика, 2005. - С. 29, 525.

3. Урология: национальное руководство [Текст] / под ред. Н. А. Лопаткина. - М. : ГЭОТАР-Медиа, 2009. $1012 \mathrm{c}$.

4. Крупин В. Н. Нейроурология : руководство для врачей [Текст] / В. Н. Крупин, А. Н. Белова. - М. : Антидор, 2005. - С. 24-31, 167.
5. Khazali S. The postmenopausal bladder [Text] / Shaaheen Khazali, Tim Hillard // Obstet., Gynecol and Reprod. Med. - 2009. - Vol. 19, № 6. - P. 147-151.

6. Каграманова Ж. О. Комплексна терапія урогенітальних клімактеричних розладів у жінок [Текст] / Ж. О. Каграманова, В. В. Малиновська, Е. Н. Вижлова // Педіатрія, акушерство та гінекологія. - 2010. - № 3 (439). - С. 107-109.

7. Сметник В. П. Неоперативная гинекология : p-во для врачей / Сметник В. П., Тумилович Л. Г. - 3-е изд., перераб. и доп. - М. : ООО «Медицинское информационное агенство», 2005. -632 c.

8. Шмелева С. В. Частота урогенитальных нарушений в зависимости от возраста [Текст] / Шмелева С. В., Карташев В. П. // Вестник восстановительной медицини. -2008 . - № 4 (26). - С. 95-97. 

WALL COMPONENTS OF WOMEN IN EARLY AND LATE MENOPAUSAL PERIODS

@B. Yu. Bidovanets, T. K. Holovata

SHEI «Ternopil State Medical University by I. Ya. Horbachevsky of MPH of Ukraine»

SUMMARY. The study was designed to characterize the ultrastructural features of reorganization of the urinary bladder wall components of perimenopausal women. The similarity of the ultrastructural changes appearance and progression which depends on age and microhemodynamics disturbances severity are shown. Therefore the non-specific dystrophic changes progress in parenchymal and stromal cells. The morphological equivalents of decreasing of the hemocapillary endotheliocytes functional activity were detected, which proves the trancapillary interchange violation, hypoxia impairment and intensification of collagen-synthesis function of fibroblasts.

KEY WORDS: urinary bladder, menopause. 